\title{
Pemeriksaan Tinggi Potensi Genetik dan Length Increments Balita Stunting
}

\author{
Lina Nurbaiti*, Deasy Irawati, Rifana Cholidah, Ardiana Ekawanti \\ Fakultas Kedokteran, Universitas Mataram, Indonesia
}

Article history

Received: 19 Agustus 2019

Revised: 23 Oktober 2019

Accepted: 20 November 2019

*Corresponding Author:

Lina Nurbaiti,

Fakultas Kedokteran,

Universitas Mataram,

Mataram, Indonesia

Email:

betty_herlin@yahoo.com

\begin{abstract}
One in four children in the world are stunted. The process of growth and development in the children under five years is a process that is very important in determining the future of the child both physically, mentally and behaviorally. Genetic ability can appear optimally if it is supported by a conducive environmental factor, which is meant by environmental factors is nutrient intake. Stunting is a national and even global issue and Sukadana Village, Teruwai, is one of the stunting village loci established by the government. Through early detection and knowing of problems with the child's development, the recovery can be done earlier, so that the child's growth and development can take place optimally. Early detection of cases of stunting children under five years by examination of high genetic potential and length increments. The results of the analysis revealed that 12 toddlers whose TB / U were normal in the first month (60\%) but whose BB / U increase decreased in the following month would be at risk of stunting if nutritional intake was not heeded. While 36 toddlers with TB / U diagnosed with stunting can be estimated to have stunted due to malnutrition, only 2 toddlers who are short due to familial short stature and 2 toddlers are likely to be stunting due to endocrine. Based on this data it can be seen what more appropriate intervention is given for stunting toddler cases. Length increments evaluated every 3 months are the best screening indicators for stunting events. There is no relationship between parental height and the incidence of stunting.
\end{abstract}

Keywords: children; stunting; length increment; familial short stature

Abstrak: Proses pertumbuhan dan perkembangan pada masa batita merupakan proses yang teramat penting dalam menentukan masa depan anak baik secara fisik, mental maupun perilaku. Kemampuan genetis dapat muncul secara optimal jika didukung oleh faktor lingkungan yang kondusif, seperti asupan gizi. Stunting merupakan isu nasional bahkan global dan Desa Sukadana, Teruwai, merupakan salah satu lokus desa stunting yang ditetapkan pemerintah. Melalui deteksi dini (pemeriksaan tinggi potensi genetik dan length increments balita) dan mengetahui masalah perkembangan anak, maka pemulihannya dapat dilakukan lebih awal, sehingga tumbuh kembang anak dapat berlangsung optimal. Hasil analisis diketahui 12 balita yang TB/U normal pada bulan pertama $(60 \%)$ namun kenaikan $\mathrm{BB} / \mathrm{U}$ nya menurun pada bulan berikutnya akan beresiko untuk mengalami stunting jika asupan gizi tidak diperhatikan. Sementara 36 balita yang TB/U terdiagnosis stunting dapat diperkirakan mengalami stunting oleh karena malnutrisi, hanya 2 balita yang pendek karena familial short stature dan 2 balita kemungkinan stunting karena endokrin. Length increments yang dievaluasi setiap 3 bulannya merupakan indicator skrining terbaik untuk kejadian stunting. Tidak ada hubungan antara tinggi badan orang tua dengan kejadian stunting.

Kata Kunci: bayi; stunting; length increment; familial short stature 


\section{PENDAHULUAN}

Satu dari empat anak di dunia mengalami stunting (de Onis et al, 2011). Di beberapa negara berkembang bahkan lebih tinggi, yakni satu dari tiga anak. Ini menunjukkan bahwa tubuh dan otak mereka gagal untuk berkembang dengan baik karena malnutrisi. Malnutrisi menjadi penyebab utama dari meniggalnya 2,6 juta jiwa setiap tahun dari sepertiga total kematian anak (Black et al, 2008). Pada tahun 2005-2011 Indonesia menduduki peringkat kelima prevalensi stunting tertinggi (WHO, 2014).

Berdasarkan hasil Riskesdas secara nasional, tahun 2007 proporsi status gizi balita pendek 18,0\%, sangat pendek 18,8; tahun 2013 balita pendek 19,2\%, balita sangat pendek 18\%; dan pada tahun 2018, angka stunting di Indonesia mencapai 30,8\% atau sekitar 7 juta anak balita terdiri dari balita pendek 19,3\% dan sangat pendek 11,5\%. Dengan kata lain, 1 dari 3 anak balita Indonesia mengalami stunting. Sementara itu, proporsi status gizi balita pendek dan sangat pendek menurut provinsi, Nusa Tenggara Timur memiliki urutan tertinggi untuk proporsi balita stunting (pendek dan sangat pendek) berdasarkan Riskesdas 2018 yaitu 51,7\% lebih tinggi dari hasil Riskesdas tahun 2013 yaitu 42,6\%. Nusa Tenggara Barat mengalami kemajuan dalam proporsi balita stunting, dimana pada tahun 2013 mencapai 37,2\% sementara di tahun 2018 menjadi 32\%, merupakan peringkat ke lima tertinggi di Indonesia (Riskesdas, 2018). Desa Sukedane, Teruwai, merupakan salah satu desa lokus stunting yang ditetapkan oleh Kementerian Koordinator Bidang Pembangunan Manusia dan Kebudayaan pada tahun 2017, dikarenakan tingginya masalah malnutrisi pada balita terutama masalah stunting yang dilihat dari koefisien stunting terbesar yang mewakili pulau Lombok.

Stunting merupakan bentuk kegagalan pertumbuhan (growth faltering) akibat akumulasi ketidakcukupan nutrisi yang berlangsung lama mulai dari kehamilan sampai usia 24 bulan (Hoffman et al, 2000; Bloem et al, 2013). Keadaan ini diperparah dengan tidak terimbanginya kejar tumbuh (catch up growth) yang memadai (Kusharisupeni, 2002; Hoffman et al, 2000).

Proses pertumbuhan dan perkembangan pada masa bayi dan balita merupakan proses yang teramat penting dalam menentukan masa depan anak baik secara fisik, mental maupun perilaku (Sunartyo, 2007). Balita hingga usia 3 tahun memiliki laju pertumbuhan yang cepat, ketersediaan zat gizi harus memenuhi kebutuhan untuk ini (Martorell, 1995). Kondisi yang berpotensi mengganggu pemenuhan zat gizi akan menyebabkan retardasi fisik dan mental (Jahari et al, 2008). Menurut Khomsan (2004) pertumbuhan fisik seseorang dipengaruhi oleh dua faktor dominan yaitu lingkungan dan genetis. Kemampuan genetis dapat muncul secara optimal jika didukung oleh faktor lingkungan yang kondusif, yang dimaksud dengan faktor lingkungan adalah asupan gizi. Apabila terjadi tekanan terhadap dua faktor di atas akan terjadi growth faltering. Pengukuran pertumbuhan penting untuk menentukan status gizi (Atmarita, 1992)

Terpenuhinya kebutuhan gizi anak akan menentukan laju tumbuh kembang anak. Potensi genetik dan pemberian zat gizi yang optimal merupakan penentu utama pertumbuhan tulang pada anak (Khairy et al, 2010). Setelah lahir, matriks tulang mengalami proses kalsifikasi, karena kalsium merupakan mineral utama dalam ikatan ini, keduanya harus berada dalam jumlah yang cukup di dalam cairan yang mengelilingi matriks tulang (Khairy, 2010). Melalui deteksi dini dan mengetahui adanya masalah pada perkembangan anak, maka pemulihannya dapat dilakukan lebih awal, sehingga tumbuh kembang anak dapat berlangsung optimal (Depkes, 2005).

Menghitung target tinggi badan dapat menginformasikan indeks pertumbuhan potensial genetic anak dengan cepat dan akurat. Seorang anak yang tinggi badannya secara persentil jauh berbeda dari target persentilnya dapat dikategorikan pendek "tidak sesuai" dengan genetic 
potensialnya dan membutuhkan evaluasi yang berkelanjutan untuk menyingkirkan adanya penyakit yang mendasari.

\section{METODE}

Metode pendekatan yang diterapkan dalam kegiatan ini meliputi pendekatan partisipatif, pendekatan kelompok, pendekatan individual, metode ceramah. Pendekatan partisipatif digunakan agar petugas kesehatan dan kader di Puskesmas ikut berpartisipasi secara aktif terhadap semua kegiatan mulai dari awal sampai akhir. Pendekatan kelompok digunakan untuk melaksanakan

1. Berdasarkan Masalah (Problem Based), yakni proses kegiatan didekatkan pada permasalahan nyata yang ada di lapangan.

2. Berdasarkan Kompetensi (Competency Based), yakni proses kegiatan dilakukan berdasarkan kompetensi yang dimiliki oleh petugas sehingga tidak terjadi miss diagnose maupun over diagnose

3. Berdasarkan Evidence Based Medicine, yakni proses diagnose dan intervensi bedasarkan EBM terkini.

Balita di ukur panjang badan atau tinggi badan sesuai prosedur standar menggunakan alat terstandar dan ditentukan status gizi nya berdasarkan $Z$ Score nya menurut WHO. Balita yang terindikasi stunting di ukur length increments serta tinggi potensi genetiknya. Setelah rangkaian diagnostic dilakukan, ditentukan intervensi masalah berdasarkan temuan klinis di lapangan.

Hasil diagnosa maupun intervensi yang tepat mengenai balita stunting disosialisasikan melalui kegiatan penyuluhan berkelompok dan diupayakan tepat sasaran. Kegiatan disosialisasikan juga ke pihak Puskesmas Teruwai dan sosialisasi di lakukan di tingkat petugas kesehatan di Puskesmas hingga kader di Posyandu.

\section{Pencapaian Tujuan}

\section{HASIL DAN PEMBAHASAN}

Antusiasme dan animo untuk mengikuti kegiatan deteksi dini kasus balita stunting dengan pemeriksaan tinggi potensi genetik dan length increments balita dengan sukarela relatif tinggi. Kehadiran dari awal hingga akhir kegiatan 98\% dikarenakan kegiatan dilakukan pada masa tanam tembakau dan $2 \%$ dari ibu/pengasuh balita meminta izin untuk tidak mengikuti kegiatan sampai selesai.

\section{Pencapaian Sasaran}

Sasaran yang dapat dicapai dalam kegiatan ini adalah 60 balita yang mengikuti kegiatan ini. Pemilihan peserta berdasarkan jumlah balita yang hadir pada saat kegiatan posyandu di 3 posyandu yang berada di Desa Sukadana dimana pada tahap awal dilakukan pemeriksaan antropometri dan dilakukan identifikasi status gizi balita berdasarkan Z Score meliputi BB/U, TB/U dan BB/TB. Jumlah total balita yang diidentifikasi status gizinya pada tahap ini sebanyak 126 balita.

Tahap awal kegiatan ini dilakukan pengukuran tinggi badan kedua orang tua akan tetapi karena Ayah dari balita kebanyakan bekerja dan tidak dapat menghadiri kegiatan Posyandu, maka tinggi badan ayah tidak dapat diukur dan tinggi potensi genetic anak juga tidak bisa dihitung. Jumlah orang tua balita yang dapat diukur tingi potensi genetiknya hanya 60 orang tua balita $(47,6 \%)$, terdiri dari 20 balita normal dan 40 balita stunting. 
Pada bulam berikutnya dilakukan pengukuran antropometri pada balita yang telah diketahui tinggi potensi genetiknya dan keseluruhan balita (60 balita) hadir. Bulan ketiga, 60 balita inipun hadir keseluruhan untuk diukur BB dan TB nya sehingga laju pertumbuhan tinggi badan balita dapat diketahui.

Hasil analisis dari TPG maupun length increament diketahui bahwa 12 balita yang TB/U normal pada bulan pertama (60\%) namun kenaikan BB/U nya menurun pada bulan berikutnya akan beresiko untuk mengalami stunting jika asupan gizi tidak diperhatikan. Sementara 36 balita yang TB/U terdiagnosis stunting dapat diperkirakan mengalami stunting oleh karena malnutrisi, hanya 2 balita yang pendek karena familial short stature dan 2 balita kemungkinan stunting karena endokrin. Berdasarkan data ini maka dapat diketahui intervensi apa yang lebih tepat diberikan untuk kasus balita stunting. Balita yang terindikasi stunting akibat kelainan endokrin dirujuk ke dokter spesialis anak untuk diperiksa lebih lanjut, sementara balita pendek karena malnutrisi dan familial short stature, orang tua atau pengasuhnya akan di berikan konseling lebih lanjut terkait pola makan dan tumbuh kembang.

\section{Pencapaian Manfaat}

Manfaat kegiatan dapat dirasakan langsung oleh balita, orang tua balita maupun kader posyandu. Kehadiran balita di posyandu pada kegiatan bulan kedua dan ketiga $100 \%$. Hal ini kemungkinan disebabkan karena orang tua atau pengasuh balita mendapatkan penjelasan lebih lanjut setelah balita mereka ditimbang dan diukur. Pada kegiatan Posyandu, antusiasme orang tua atau pengasuh dilihat dari banyaknya pertanyaan yang muncul ketika tim pengabdian menjelaskan kondisi balita mereka. Kegiatan kami termasuk dalam kegiatan posyandu meja ke lima.

Peranan posyandu sangat penting bagi masyarakat, meskipun umumnya posyandu masih belum memaksimalkan peran 5 meja yang seharusnya dilakukan oleh dinas kesehatan dalam hal ini biasanya oleh bidan atau ahli gizi dan dibantu para kader posyandu. Umumnya beberapa posyandu hanya melakukan pelayanan pendaftaran, kemudian penimbangan, pengukuran tinggi badan, imunisasi dan pencacatan di buku KIA serta PMT.

Meja kelima masih belum efektif secara maksimal, dimana meja ke lima adalah pelayanan konseling mengenai makanan yang bergizi, murah, mudah didapat serta pemeriksaan deteksi dini tumbuh kembang anak dan penyakit pada balita.

\section{Analisis Faktor Penghambat}

Tidak ada faktor peghambat yang bermakna dakam kegiatan ini. Tempat pemeriksaan yang sangat sederhana dan minimalis, hanya beralaskan tikar tidak menyurutkan antusiasme orang tua atau pengasuh balita untuk tetap antri untuk diperiksa dan konseling.

\section{Analisis Faktor Pendorong}

Kerjasama yang baik antara pihak FK UNRAM, Puskesmas Teruwai dan Kepala Desa Sukedana, sehingga kegiatan dapat berlangsung dengan lancar dan meriah 

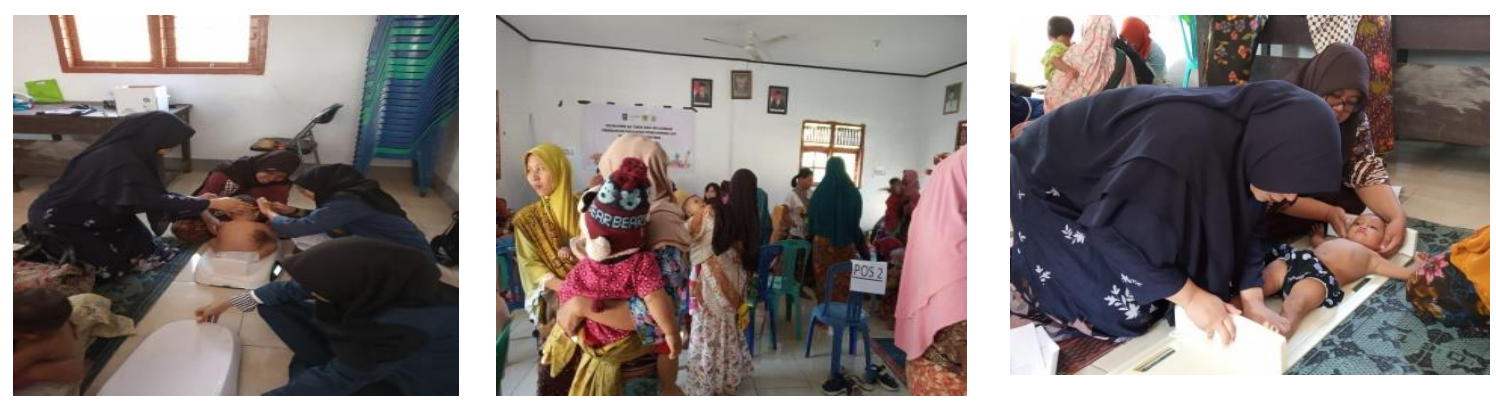

Gambar 1 Pengukuran Antropometri ( Berat Badan dan Panjang Balita)

Disertai Deteksi Dini Tumbuh Kembang dan Konseling

\section{Kesimpulan}

\section{KESIMPULAN DAN SARAN}

Pelaksanaan kegiatan pengabdian kepada masyarakat berupa Deteksi dini kasus balita stunting dengan pemeriksaan tinggi potensi genetik dan length increments balita telah dilaksanakan sesuai dengan apa yang diharapkan. Length increments yang dievaluasi setiap 3 bulannya merupakan indicator skrining terbaik untuk kejadian stunting. Tidak ada hubungan antara tinggi badan orang tua dengan kejadian stunting. Target luaran dari kegiatan pengabdian ini yaitu kasus balita stunting dapat didiagnosa dengan tepat dan diketahui intervensi awal yang tepat untuk dapat mengatasi masalah stunting pada balita tersebut telah kami capai.

\section{Saran}

Kegiatan ini dapat menjadi kegiatan pendahuluan untuk upaya pendampingan Posyandu Balita. Dapat dilakukan upaya tindak lanjut untuk melakukan pendampingan dan upaya monitor evaluasi kegiatan yang berkelanjutan

\section{Ucapan Terima Kasih}

Penulis mengucapkan terima kasih kepada LPPM Unram melalui Sumber Dana DIPA BLU (PNBP) Tahun 2019 Universitas Mataram yang telah memberi dukungan financial terhadap pengabdian ini.

\section{DAFTAR PUSTAKA}

Atmarita, Veronica L.,1992. Penggunaan Indeks Massa Tubuh (Body Mass Index) Sebagai Indikator Status Gizi Orang Dewasa, 17(1/20): 50-56, Indonesia

Black R.E., $\quad$ Valentiner-Branth P., Lanata C.F., 2008. Multicountry analysis of the effects of diarrhoea on childhood stunting. International Journal of Epidemiology, 37

Bloem MW, Pee SD, Hop LT, Khan NC, Laillou A, Minarto, Pfanner RM, Soekarjo D, Soekirman, Solon JA, Theary C, Wasantwisut E, 2013. Key strategies to further reduce stunting in Southeast Asia: Lessons from the ASEAN countries workshop. Food and Nutrition Bulletin: $34: 2$

de Onis, M Blossne and E Borghi, 2011. Prevalence of stunting among pre-school children 19902020: Growth Assessment and Surveillance Unit. Public Health Nutrition. Jul 14:1

Depkes RI. 2005. Pedoman Pelaksanaan Stimulasi, Deteksi dan Intervensi Dini Tumbuh Kembang Anak Di Tingkat Pelayanan Kesehatan Dasar. Hal: 4, 7, 11, 45 - 53. Indonesia 
Hoffman DJ, Sawaya AL, Verreschi I, Tucker KL, Roberts SB, 2000. Why are nutritionally stunted children at increased risk of obesity? Studies of metabolic rate and fat oxidation in shantytown children from São Paulo, Brazil. Am J Clin Nutrition 72:702-7

Jahari AB, Sandjaja, Sudiman H, Jus'at I, Jalal F, Latief D, Atmarita. 2000. Status Gizi Balita di Indonesia Sebelum dan Selama Krisis: Analisis Data Antropometri Susenas 1989-1999. Prosiding Widyakarya Nasional Pangan dan Gizi. Jakarta: LIPI

Khairy SAM, Mattar MK, Refaat LAM, ElSherbeny SA. 2010. Plasma micronutrient levels of stunted Egyptian School age children. Kasr El Aini Med J. 16(1):1-5. 8.

Khomsan, A. 2004. Peranan Pangan dan Gizi untuk Kualitas Hidup. Penerbit PT Gramedia Widiasarana Indonesia. Jakarta

Kusharisupeni, 2002.Growth Faltering pada Bayi di Kabupaten Indramayu Jawa Barat. Makara Kesehatan, 2002, 6:1-5

Martorell R. 1995. Promoting Healthy Growth: Rationale and Benefits. In Child Growth and Nutrition in Developing Countries. In Andersen PP, Pelletier D and Alderman H. Itacha: Cornell University Press

Riskesdas. 2018. Laporan hasil riset kesehatan dasar 2018. Jakarta: Badan Penelitian dan Pengembangan. Kesehatan Kementerian Kesehatan Republik Indonesia

Sunartyo, N. 2007. Panduan Merawat Bayi dan Balita. Jogjakarta: Diva Press. Hal: 11 -19

World Health Assembly. 2014. Global nutrition targets 2025: Stunting policy brief. Geneva. 